\title{
Availability of Books and Other Informational Materials and the Use of Academic Libraries. Awana, 0.
}

\begin{abstract}
.
Gone are the days when librarians perform duties manually except for the few libraries that have not automated their services. Ability to store up-to-date materials, retrieve them for use by the prospective users is very important. $A$ good library is judged by the effective utilization of the resources of the library. The materials must be accessible to their users without the wastage of precious time.

With the advent of computers and the internet, library operations have become simplified, faster, more accurate and current. Learning, teaching and research have become more interesting and less stressful as it used to be.

Fears been expressed in some quarters that with the advent of computers and internet in libraries, the traditional librarians may become redundant and irrelevant in the scheme of things, may not be $100 \%$ correct as there are some minute and local information that may be so necessary to the researcher that may not be the internet Serials/periodical should be given proper place in the acquisition policy in any academic library in such a ration of 70:30 for books and periodicals respectively. Proper retrieval system should be put in place so that the materials so acquired will be put into judicious use.
\end{abstract}

\section{Introduction}

Before a library could be adjudged to be effective, it must be meeting the information, research, 
recreational and educational needs of the users (Clarke, 1997).

Books and other information disseminating media are very important in libraries so that they can function properly to achieve the objectives for which they are set up to attain. The materials which should be current should be made available and accessible to the potential users in good time.

Nwalo (2001) stated that library effectiveness measures are concerned with determining how well the library meets the needs of users, relative to the library's goals and objectives. As far back as 1955, convey had made library effectiveness the subject of serious research and since then a lot of studies have been carried out in this direction. Opinions vary on the best way to determine library effectiveness. While some canvassed the application of standards, other prefer the use of statistics and others operations research and others, user satisfaction. However, the most recent literature on library effectiveness emphasizes the user approach. Mackenzie in Nwalo refers to user approach to performance measurement as "market research".

Similarly Oyesiku and Akinbode (2004) state that libraries are established for the use of the people effectively. As some people recognize the potential value of libraries and make maximum use of them so also some people do not use them or encourage their use. Factors that affect the effective use of academic libraries according to Marteleto (1981), Unomah (1987), Dina (1983), Okiy (1999 \& 2000) and Irehovbude (1981) are due to unavailability syndrome and inadequate library resource facilities and services. Also on effectiveness. Ologbonsaiye (1994), states that the yardstick for measuring users' (patrons) satisfaction include:

* The quality of a library's collections and services. 
* Availability of materials for use in the types and accessibility to users...

In the same vein, Oberuomo (2003) is of the view that for a successful research to be carried out, the researcher should be aware of existing knowledge of similar works and have access to information that would enable him build up his own theory of knowledge. He should also have the resources for such objectives and all the necessary information that maybe needed. The researcher's time is saved as library organizes materials in such a way that they can easily be retrieved, in line with Ranganathan's 4th law that says "save time of the reader". Ranganathan,(1957). With the exponential growth in literature which has made resources many and scattered, the library collects these sources of informational materials and packaged them in such a way that they are easily retrievable by researchers.

The library must acquire and house materials that will meet the aims and objectives of the parent body selection of library materials must be a joint effort by the librarian, the academic and senior non- teaching staff and the students if a balanced collection must be achieved. Aguolu and Aguolu (2002) supporting this view, noted that librarians are expected to collaborate with the teaching staff in building up the library collection and in orienting the students interest to effective library use. In like manner, Achebe (1998) emphasized on the expected role of lecturers in the modern method of education that is inevitably based on "Resources Based Learning" (R.B.L) in which the library plays a major role. Dike (1990) observed that if the R.B.L is to succeed, lecturers/teachers are therefore expected not to rely so much on their classroom lecture and lecture notes but to guide and direct students to the library on how to locate information on their own. Selection of library materials for the academic 
libraries should be done by the librarian but with consultation with the faculty members, (Awana 1999). He further added that librarians with their professional training and experience should be able to know what is good and needed in the type of library he mans.

Adequate supply and availability of up-to-date relevant reading textbooks, journal and reference materials to aid users in their academic pursuit, will attract users to an academic library. Adequate supply and availability of materials must be matched with accessibility by users. Unomah (1986) sees user education on how to use the resources of the library in this regard, as very essential. He believes that users of academic library should be given proper library orientation on the use of materials in the library.

Supply of serials/periodicals and newspapers should be given proper attention. These are library materials that aid research as they contain reports of recent happenings, research findings which are too recent or fresh to be contained in textbooks and if users are aware of their presence, they would be happy to patronize such libraries for effective utilization.

Adequacy of services rendered in the library tells a lot of success story about the library. This can be judged from the availability, organization and accessibility of such questions as: How are the reference services performed? Are there indexing and abstracting services? How is the selective dissemination of information (S.D. I) functioning? Answers to these pertinent questions help a long way to determine and evaluate the use or non-use of a library or its materials.

Uwem (2003) says acquisition of information resources would be a waste of funds if the resources are not consulted by users. Tables, chairs, shelves and other library infrastructure would be object of decorations if they were not 
enabling facilities for access to and use of information. From acquisition to processing and organization, the critical consideration is in meeting users' needs. It is not necessary to argue with users at points of service provision in the library. As the adage states that "the customer is always right" in business transactions, so also it is in the library provision of services. She further stated that if the library exists to service the information needs of the clientele, the only logical starting point in addressing those needs, is the proper diagnosis. A firm understanding of users' need is beneficial to both the library and the actual and potential users. She gave the following reasons why user needs should be thoroughly understood to be:

* To enable the library concentrate scarce funds in the acquisition of need-based resources.

* To organize the resources according to the subject profile of the users

- Prompt provision of what is needed from what is wanted

* Right information delivery to the right person.

* Easy retrieval of information because the library system has been designed from the stand point of the users.

It is a known fact that standard textbooks are no longer in adequate supply in academic libraries or at the reach of students and teachers. Books, if available are so expensive, that even the institutions, students and teachers find it difficulty to acquire copies of required books. More worrisome is that various governments seem not to be taking matter of adequately funding libraries seriously; instead they concentrate on issue of falling standard in education instead of finding solution to the problem. Due to lack of fund, most libraries do not stock standard and adequate materials which 
would have made users to patronize such libraries. National Universities Commission ( NUC) and the National Commission for Colleges of education (N.C.C.E) came out with policies that $5 \%$ of the institutions capital budget be kept for libraries budget, but this is hardly complied with by any institutions instead the little kept for library development is quickly diverted to other areas in times of "urgent needs".

Ogunsola (2004) states that the university libraries have long been recognized as the "hearts" of their universities to fulfill their mission of supporting the educational objectives of the parent bodies, which include; teaching, learning, research and cultural development. The libraries have to develop and maintain standard books, journals and Audiovisual collections and services. During the "oil boom" era, Petroleum Trust Fund (P.T.F), the libraries flourished-they were busy filling their shelves with learning materials in order to sustain the main academic disciplines established by their parent institutions. Today, the story is very different. Academic libraries have problems even in maintaining their core collections which represent their institutions curricula and academic activities because of lack of money and high rate of inflation and high exchange rate for books imported.

Awana (2000) opined that reading materials, no doubt, are one of the essentials or important resources needed for effective learning of any course or subject. They will continue to be one of the main sources of information and knowledge to both students and teachers. Textbooks are needed to enhance effective learning and teaching in an institution and they should meet the challenges and the increasingly dynamic concepts of education and learning. However, if the needed materials are not available, then frustrations set in. Unomah(1986) proved this to be correct in a research on unavailability syndrome in academic library. He said that 300 
[71.43\%] of his respondents went home frustrated when they failed to get what they wanted.

The resources of the library are essential input in the learning process and for the over all assessment of the educational objectives and achievement. Advances in technologies have ensured that library resources have gone beyond the print media-electronic, multimedia, the internet have made a lot of impact on the availability of reading materials. This is a very big task for the library profession, and librarians must brace up to face the new challenges, if they must remain relevant in the scheme of things.

Periodicals/serials, like books, form part of the reading materials in an academic library. Periodicals and serials are publications issued at regular intervals and which as a rule, are intended to be published indefinitely. Periodicals maybe published daily weekly, monthly, bi-monthly, quarterly or yearly. They usually have volume and issue numbers, month and year of publication. Okolo (2002) Periodicals may be divided into two classes, namely: general periodicals and professional periodicals. A general periodical is not restricted to one subject area only, while the professional periodicals are those that are restricted to one or two subject areas only or branches of knowledge.

Most library users who are aware of the existence of periodicals do not know how to put them into proper use let alone those who are ignorant of their existence as a result, most users find it difficult to use periodicals.

How then are periodicals used? Most libraries produce or prepare indexes or abstracts to the articles in periodicals (which are usually arranged in Kadex or Kalamazoo or displayed in shelves like books or in periodical racks to aid quick access or location of such articles in the periodicals such 
indexes or abstracts to the articles may usually contain the authors, title of the article, title of the periodical, volume number and issue number, month and year of publication and the page number. An abstract may go further down to give a brief summary of what the article is all about. Uwem (2003). All these information can be either recorded in a notebook or in a card in the Kadex. According to Ejimkonye and Nwogu (1991) periodicals play very important and useful roles in libraries. Current information on a subject or topic especially, medicine, agriculture, science, engineering and technology are usually first found in periodicals before textbooks can carry such information. Current information, trends and development in science, technology, economics, and international politics etc are traced easily in periodical literature. Serials contain book reviews, notices of professional information, conferences, seminars and subject or topic that are very new, too small and temporary to be covered in textbooks are usually found in serials. Serials disseminate research information and information on forthcoming books are also found in serials. Every good library should, take the subscription and acquisition of serials a priority as serials are sort of indispensable tools in every library as they help and promote research and scholarship in no small measure. Library authorities, especially the academic libraries should strive so hard to endeavour to make sure that they acquire periodicals in all subjects relevant to the parent body's academic programmes. As primary source materials, they provide concise information and in many cases they cite references or bibliography consulted. Periodicals are indispensable tool for the latest ideas and information in teaching and learning.

Also unavailability syndrome in academic libraries could cause frustration and lack of use among users of the 
library. In a study carried out by Unomah (1987) revealed that failure to get the title they wanted, users gave up the search and went home disappointed. However, Awana (2000) said that "unavailability" syndrome could be attributed to user's error. By this he meant that the book may actually be available but that the user did not consult all appropriate search strategies for the location of the materials, especially the catalogue. Some users may walk straight to the shelf to find a needed material. But when the materials are not there they will not ask question or find answers from the librarian. Maybe the books, for one reason or the other has, been withdrawn from circulation or on loan to a reader. Library frustration could be that if the book is not in the shelf for them to pick then the library is not living up to its bidding and expectation. Another aspect of reader or user error could be that when he has a topic to write on, he walks into the library and goes straight to the shelf, if he can not get the exact topic among the titles of the books on the shelves, then the library is dead. Unknown to them that the topic he is looking for could be gotten from the content pages or index pages of any other book. It should be borne in mind that index to book or library catalogue could provide alternative reading materials to a topic. Still on the availability of materials, Gates (1994) says that the major concern of the academic library is to satisfy the information needs of academic patrons by providing them with the needed materials. Based on this fact, the academic library is built based on her parents/mother objectives. Also Okiy (1999 \& 2000) states that the main reason why libraries exist is to provide the right materials to meet the information needs of their users". Adomi (1998) while sharing the same view revealed that the 
most comfortably used place for reading, is the library. In that regard, Ifidon (1999) suggested that the library should contain all those great works in science and literature which are either too difficult or expensive for individuals to procure, this would go a long way to ameliorate the problems associated with the increasing cost of library materials. Dike (1992) viewed the development of reading habit, information-handling skills and the linking of library objectives to resources available in various subject areas of the parent institutions.

Table 1: Utilization of Library Resources.

\begin{tabular}{|c|c|c|c|c|c|}
\hline \multirow{2}{*}{$\begin{array}{l}\text { S/ } \\
\text { N }\end{array}$} & \multirow[t]{2}{*}{ Items } & \multicolumn{4}{|c|}{ Total Respondent (300) } \\
\hline & & Agree & $\%$ & Disagree & $\%$ \\
\hline 1 & $\begin{array}{l}\text { Your institution library has adequate } \\
\text { and relevant textbooks to satisfy } \\
\text { your academic needs }\end{array}$ & 180 & 60 & 120 & 40 \\
\hline 2 & $\begin{array}{l}\text { The journals/magazines and } \\
\text { newspapers in your college library } \\
\text { are just suitable and relevant in } \\
\text { meeting your academic pursuit. }\end{array}$ & 160 & 53 & 140 & 47 \\
\hline 3 & $\begin{array}{l}\text { Your school library has all the } \\
\text { necessary non-book materials to aid } \\
\text { you in your academic work }\end{array}$ & 100 & 33 & 200 & 67 \\
\hline 4 & $\begin{array}{l}\text { Needed material that are not } \\
\text { available in your library are provided } \\
\text { for you an request from other } \\
\text { libraries }\end{array}$ & 105 & 35 & 195 & 65 \\
\hline
\end{tabular}

In a survey research conducted by Awana (2006) on Availability of infrastructural materials in some colleges of Education in Delta State, Nigeria, the findings below were recorded as deduced from the table above.

Asked whether the institution's library has adequate and relevant textbooks to satisfy their academic needs, 180 $(60 \%)$ of the 300 respondents disagree while 120 or $(40 \%)$ agree. Also asked whether the journals/magazines/ newspapers in the college library are relevant and suitable for 
their use; 160 (53\%) out of the 300 respondents agree while $140(47 \%)$ disagree. Similarly when asked whether the college library has all the necessary non-book materials to aid them in their academic work, $100(33 \%)$ of the total respondents of 300, agree while $200(67 \%)$ disagree. When asked whether needed materials that are not available in their library are provided for them from other libraries, on request, through inter-library loan, 105 (35\%) agreed while 195 (65\%) disagreed.

From the above data analysis, it could be seen that most academic libraries are not performing their roles adequately, as relevant books, journals and Audio-visual materials are not adequately provided for the users. Also needed materials which are not available in their libraries are not provided for them through inter-library loans cooperation.

\section{Findings}

In response to the Research Question "Does lack of informational materials affect the use of Academic library? The finding of this research question was that lack of informational materials is one of the factors affecting the use of academic library resources. This finding collaborates with Marteleto (1981) Unomah (1987), Dina (1983), Irehovbude (1981), and Ologbensaiye (1994) who respectively noted that factors which affect the effective use of academic libraries are the unavailability syndrome and inadequate library resources, facilities and services.

\section{Conclusion}

Academic libraries acquire, organize, store and disseminate information. But the services as well as the utilization of the libraries and their resources do not seem to 
be easy and encouraging due to certain factors. As a result of the findings of this study, the following conclusions are hereby drawn.

Academic libraries more often than not do not stock current and relevant information materials to attract readers. When a needed material by a reader is not available in one library, the material is not borrowed from the library that has it for the user who wants it

\section{References}

Achebe, N.E.E (1998) "Effective Application of Resources Based Learning in a low budget Multi-programme University System". Nigerian libraries 32 (1) 41-49

Adomi, E.E (1998). "The Reading setting of some students at University of Ibadan, Nigeria". Delta Lib. Journal 1 (1) 1-7.

Aguolu, C.C and Aguolu, I.E (2002) Libraries and Information Management in Nigeria. Maiduguri: Ed - Linforn Services.

Akinbode, R.O (1996). "University Library Services and Information Needs of Students and Staff in an Academic Community". Le Professeur Vol. 4 .41-42.

Awana, B.O. Introduction to Library Science. Agbor: Royal Pace Pub.

Awana, B.O. (2000) How to Use the Library. Asaba: Alcel Concerns.

Awana, O. (2006) "Assessment of the Factors Affecting the Effective Utilization of Library Resources in College of Education in Delta State, Nigeria". DELSU, Abraka. Unpublished M.Sc (Library \&Information Science) Dissertation.

Clarke, S.O. (1997) Fundamentals of Library Science. Warri: COEWA Pubs. 
Dike, V.W. (1992) Library Resources in Education. Enugu: ABIC Publishers.

Dina, O (1983) "Attitude of Students towards Library Use and Services: University of Lagos as a Case Study". Unpublished M.L.S. Thesis; University of Ibadan. Ibadan.

Ejimkonye, C.N and Nwagu, P.I. (1991) Basic Librarianship. Owerri: Totan Publishers

Gates, J.K (1994) Guide to the Use of Books and Information Sources. U.S.A: Domelley and Sons.

Ifidon, S. E. (1999) Essentials of African University Library Management. Lagos: The National Library Pr.

Irebovbude, M.O. (1991) "Undergraduate Students Perception of Academic libraries; A case study of University of Ibadan". Unpublished M.L.A. Thesis; University of Ibadan. Ibadan.

Marteleto, R.M. (1981) "Lecturers Information Needs and the Interaction between University Libraries". UFMA Vol. 13(1). 123-138.

Nwalo, K (2001). "Effectiveness of Polytechnic Libraries in Nigeria". Journal of Librarianship and Information Science in Africa. Vol. 1 (1) 41-50.

Oberuomo, Warren O. (2003) Undergraduate Attitude towards the Use of Academic Libraries: A case Study of the Delta State University, library, Abraka. Published B.L.S. project of DELSU, Abraka.

Ogunsola, L.A. (2004) Nigerian University Libraries and the Challenges of Globalization: The way forward. Electronic Journal of academic and special Librarianship. Vol. 5(2\&3) Fall. 1 of 10.

Okiy, R.B. (1999\& 2000) "Assessing Students and Faculty Use of Academic Libraries; The case of Delta State 
University, Abraka: Nigerian Journal of Library \& Information Science vol. 3 \& 4. 52-60

Okolo, E.O. (2000) The Use of the Library for Students in Tertiary Institutions. Ibadan: End Time Publishing House Ltd.

Ologbonasaiye, R.(1994) Resources Management for Librarians. Lagos: Concept Publishers.

Onyesiku, F.A and Akinbode, R.O (2004). A study on User Satisfaction with the Services of Private University Libraries. A Case Study of Babcock University Library, Nigeria. NLISR Vol. 22 (1). 21-28

Unomah, J.I. (1986) Students Utilization of Academic Libraries in Nigeria: An assessment. Nigerbiblios Vol. 1(4). 4-8.

Unonah, J.I. (1987) "Unavailability Syndrome in Academic Libraries: A Case Study of Bendel State University Library, Ekpoma", Nigeria library and Info Science Review Vol. 3 (1\&2). 38-46

Uwem, E. (2003)" Readers Services at Crossroads: Meeting Users Needs in the Information Age. Lagos Journal of Library and Information Science. Vol. 1(2). 113-119.

Zaki, N (1991). Use Education in Nigerian universities. The Need for New Approaches. International Library Movement Vol. (1) 27- 43. 